\title{
5 Primary care management
}

\author{
Jean-Marie Degryse, Ruth Kalda, Roar Maagaard, \\ Phil Phylaktou, Howard Tandeter, Peter Vajer, \\ Yvonne van Leeuwen, Natalia Zarbailov
}

\section{Primary care management includes the ability:}

- To manage primary contact with patients, dealing with unselected problems;

- To cover the full range of health conditions;

- To co-ordinate care with other professionals in primary care and with other specialists;

- To master effective and appropriate care provision and health service utilisation;

- To make available to the patient the appropriate services within the health care system;

- To act as advocate for the patient.

\subsection{Introduction}

In everyday practice primary care management involves taking the history and systematic assessment of the patient, making a proper diagnosis, responding appropriately to the patient needs, cooperating with other team members and health care specialists in order to offer proper services for the patient as well as preventing unnecessary services and treatment. This includes the system of record-keeping and information management and ways of organizing care within a practice or PHC team.

Primary Care Management should reflect the following traits:

- Knowledge about epidemiology of problems presented by patients in primary care;

- Understanding of the natural history of common conditions;

- Skills for working with colleagues and in team;

- Understanding of the structure, roles and responsibilities of the he primary health care team as being ever larger and more complex;

- Understanding of the primary care organization and informational medical technologies; 
- $\quad$ Ability to provide effective problem management with drug and non-drug approaches;

- Effective communication skills;

- Value the primary care approach;

- Understanding of the probabilities and evolution of conditions in primary care which comes principally through experience therefore is often not fully developed until after formal training.

\subsection{Assessment methods}

Assessment of primary care management skills requires a variety of methods:

Case based discussion (CBD), structured oral interview used in general practice, across a range of competency areas; the starting point is the written record of cases selected by the GP.

Consultation observation tools (COT), tools to assess consultation skills, can be used to assess video recorded consultations or during direct observation in general practice settings.

Multi-source feedback (MSF), assessment of clinical ability and professional behaviour, rated by five clinical colleagues, two occasions or rated by five clinical and five non-clinical colleagues on two occasions; needs skill of assessor in giving feedback.

Naturally occurring evidence (NOE), from direct observation, "tagged" against appropriate competency headings, other practice-based activities, clinical supervisor's reports (CSR).

Patient satisfaction questionnaire (PSQ), measures consultation and relational empathy, can differentiate between doctors; needs skill of assessor in giving feedback.

Performance audit (PA) refers to an examination of a programme, function, operation or the management systems and procedures to assess whether the entity is achieving economy, efficiency and effectiveness in the employment of available resources. The examination is objective and systematic, generally using structured and professionally adopted methodologies.

Review of patient records (RPR), review of the collection of documents that provides an account of each episode in which a patient visited or sought treatment and received care or a referral for care from a health care facility. 
Simulated patient (SP), or standardized patient (SP) (also known as a patient instructor) in health care is an individual who is trained to act as a real patient in order to simulate a set of symptoms or problems.

\subsection{Documentation tools}

A variety of tools can be used: Patient satisfaction questionnaires, consultation assessment tools, portfolios etc. One possible example of assessment of chronic patient management is given below:

\begin{tabular}{lllllll}
\hline Characteristic & \multicolumn{3}{l}{ Quality level: } & & & \\
from $\mathbf{1}$ (is not done at all) & $\mathbf{5}$ (done appropriately) \\
\hline Assessment of Patient's Needs & 1 & 2 & 3 & 4 & 5 \\
\hline Goal Setting/Action Planning & 1 & 2 & 3 & 4 & 5 \\
\hline Problem-Solving & 1 & 2 & 3 & 4 & 5 \\
\hline Emotional Health Assessment & 1 & 2 & 3 & 4 & 5 \\
\hline Patient Involvement & 1 & 2 & 3 & 4 & 5 \\
\hline Patient Social Support & 1 & 2 & 3 & 4 & 5 \\
\hline Patient Self-management Education & 1 & 2 & 3 & 4 & 5 \\
\hline Continuity of Care & 1 & 2 & 3 & 4 & 5 \\
\hline Coordination of Referrals & 1 & 2 & 3 & 4 & 5 \\
\hline Case Documentation & 1 & 2 & 3 & 4 & 5 \\
\hline
\end{tabular}

\subsection{Abilities}

\section{Ability 1: To manage primary contact with patients, dealing with unselected problems.}

Case vignette.

Chris Butler, a man of 58 years of age, visits his GP as the last patient of a row of 20 , just before $6 \mathrm{pm}$. The patients of that afternoon had a variety of problems, e.g. onychomycosis, postpartum depression, diabetes mellitus type 2 and a tumour in the left breast. Ten however, had complaints that could easily be related to the flu, of which there is an epidemic outbreak at that moment. Chris Butler complains of "not feeling well" and aching of his thoracic muscles. He asks for "something against the flu", because he does not want to take time off from work. The GP, however, asks him to answer some questions, first. The reason to do so, at this late hour, is 
that this patient rarely visits the practice, has a family history of cardiovascular disease (several heart-attacks before the age of 60) and looks "off". The history and physical examination increases the GPs gut-feeling that there is something serious going on: the patient reports that the muscular aching is exercise-related, his forehead is moist, he has a tachycardia (100/min) and his blood pressure is $175 / 110$ $\mathrm{mmHg}$. The wife is phoned by the practice nurse and the ambulance is ordered. The GP phones the cardiologist. 20 minutes later Chris Butler leaves the practice in the ambulance with the diagnosis: suspect of myocardial infarction.

\begin{tabular}{|c|c|c|}
\hline Features of this ability & Assessment method & Who could assess? \\
\hline $\begin{array}{l}\text { Does the GP show his/her ability to include } \\
\text { facts form earlier contacts and family history? }\end{array}$ & \multirow{4}{*}{$\begin{array}{l}\text { - Simulated patients } \\
\text { - Video observation } \\
\text { - Trainers opinion }\end{array}$} & \multirow{4}{*}{$\begin{array}{l}\text { - Staff } \\
\text { - Trainer } \\
\text { - Observers } \\
\text { - Test evaluator }\end{array}$} \\
\hline $\begin{array}{l}\text { Does the GP interpret undefined complaints } \\
\text { well, in spite of: low likelihood or misleading } \\
\text { circumstances (flu epidemic)? }\end{array}$ & & \\
\hline $\begin{array}{l}\text { Does the GP take time to carefully inter- } \\
\text { rogation and examination despite the time } \\
\text { pressure? }\end{array}$ & & \\
\hline $\begin{array}{l}\text { Does the GP know morbidity figures related } \\
\text { to patient characteristics? }\end{array}$ & & \\
\hline
\end{tabular}

Table 5: To manage primary contact with patients, dealing with unselected problems

\section{Ability 2: To cover the full range of health conditions.}

The doctor has to bring a patient list for the previous (full) day - that is a list showing all the patients seen in the clinic by this doctor on the previous day. It should include:

- Sex;

- Age;

- Reason for encounter;

- Medical records for the patients on the list.

This list should be brought for discussion with the trainer/supervisor. 


\begin{tabular}{l|l|l}
\hline Features of this ability & Assessment method & Who could assess? \\
\cline { 1 - 2 } $\begin{array}{l}\text { A list demonstrating a variety of } \\
\text { patients regarding sex, age and } \\
\text { reasons for encounter }\end{array}$ & $\begin{array}{l}\text { - Review of patient records } \\
\text { - Discussion with supervisor/ } \\
\text { trainer }\end{array}$ & $\begin{array}{l}\text { - Trainer } \\
\text { - Peer }\end{array}$ \\
\cline { 1 - 2 } $\begin{array}{l}\text { The doctor demonstrates in the } \\
\text { medical records and in the dis- } \\
\begin{array}{l}\text { cussion that he is working with } \\
\text { the problems presented to him. }\end{array}\end{array}$ & & - Educational authority \\
\hline
\end{tabular}

Table 6: To cover the full range of health conditions

\section{Ability 3: To co-ordinate care with other professionals in primary care and with other specialists.}

Case vignette.

Monica Gustavsson, a 63 years old female patient with diabetes mellitus type 2, shows up with a chronic ulcer on the left lower limb. The ulcer has been treated according to the doctor's instructions. Monica attends for a check-up after three weeks; the nurse makes the observation that she sees no improvement, telling the patient: "If things continue this way you are going to have serious problems, losing your leg because of the doctor." The nurse goes to doctor saying it is his fault that Monica Gustavsson's wound is not improving. How should this situation be handled?

\begin{tabular}{|c|c|c|}
\hline Features of this ability & Assessment method & Who could assess? \\
\hline $\begin{array}{l}\text { Minimum time spent in contact with } \\
\text { other professionals }\end{array}$ & \multirow{3}{*}{$\begin{array}{l}\text { - Patient satisfaction } \\
\text { - Multisource feed- } \\
\text { back (computerized } \\
\text { possibility) } \\
\text { - Performance audit }\end{array}$} & \multirow{3}{*}{$\begin{array}{l}\text { - Patient } \\
\text { - Other medical profession } \\
\text { - Trainer }\end{array}$} \\
\hline $\begin{array}{l}\text { Notes in the medical file of the opin- } \\
\text { ions of the others, or using integrated } \\
\text { system of database, access to hospital } \\
\text { patients records }\end{array}$ & & \\
\hline $\begin{array}{l}\text { Patient satisfaction in observing team- } \\
\text { work }\end{array}$ & & \\
\hline
\end{tabular}

Table 7: To co-ordinate care with other professionals in primary care and with other specialists 


\section{Ability 4: To master effective and appropriate care provision and health service utilization.}

Case vignette.

The GP is called for neonatal visit to the 9 days old baby Caroline. She knows the family well. The mother is a 39 years old lady and during the first period of the pregnancy she supported flu. At the visit the parents look very sad and discouraged. According to the medical conclusion given from maternity hospital Caroline has serious health problems.

\begin{tabular}{l|l|l}
\hline Features of this ability & Assessment method & Who could assess? \\
\hline $\begin{array}{l}\text { Does the GP think to involve } \\
\text { another care provider? }\end{array}$ & - Discussion with GP & - Trainer \\
\hline $\begin{array}{l}\text { Does the GP assess patient } \\
\text { needs? }\end{array}$ & $\begin{array}{l}\text { - Direct or video observation } \\
\text { - Review of patient records }\end{array}$ & - Peer \\
\hline $\begin{array}{l}\text { Does the GP has knowledge } \\
\text { about health care structure and } \\
\text { he goes to contact the right } \\
\text { persons, to use all available } \\
\text { recourses? }\end{array}$ & $\begin{array}{l}\text { - Patient satisfaction ques- } \\
\text { tionnaire }\end{array}$ & - Other health care providers \\
\hline $\begin{array}{l}\text { Does the GP have good com- } \\
\text { munication with other health } \\
\text { care providers? }\end{array}$ & & \\
\hline
\end{tabular}

Table 8: To master effective and appropriate care provision and health service utilization 


\section{Ability 5: To make available to the patient the appropriate services within the health care system.}

Case vignette.

Maria Parini, a 56 years old female patient visits her GP because of chronic low back pain lasting more than four months. She was examined thoroughly by her GP and has no serious disease needing neurosurgery. She has sleeping problems, is tired because of pain, depressed and seems disturbed. Maria Parini works as salesclerk in a little shop, and has difficulties being on her feet all day. She uses NSAIDs, which have little or no effect.

\begin{tabular}{|c|c|c|}
\hline Features of this ability & Assessment method & Who could assess? \\
\hline $\begin{array}{l}\text { Does the GP show good communication skills } \\
\text { covering all possible affects of the pain to the } \\
\text { patient everyday life: physiologic, psychological } \\
\text { and psychosocial aspects? }\end{array}$ & \multirow[t]{4}{*}{$\begin{array}{l}\text { - Simulated patients } \\
\text { - Video observation } \\
\text { - Discussion with trainer }\end{array}$} & \multirow[t]{4}{*}{$\begin{array}{l}\text { - Simulated patient } \\
\text { - Trainer } \\
\text { - Peer }\end{array}$} \\
\hline $\begin{array}{l}\text { Does the GP take enough time for detection } \\
\text { possible psychosocial, environmental or social } \\
\text { barriers to recovery (job dissatisfaction, depres- } \\
\text { sion or anxiety disorder etc.)? }\end{array}$ & & \\
\hline $\begin{array}{l}\text { Does the GP involve to the treatment spine- } \\
\text { care education and active exercise pro- } \\
\text { grammes using physiotherapists, back-schools, } \\
\text { cognitive-behavioural support or other available } \\
\text { resources? }\end{array}$ & & \\
\hline $\begin{array}{l}\text { Does the GP use tricyclic antidepressants as } \\
\text { approved treatment of chronic back pain? }\end{array}$ & & \\
\hline
\end{tabular}

Table 9: To make available to the patient the appropriate services within the health care system 


\section{Ability 6: To act as advocate for the patient.}

Case vignette.

Dusan Smilic is a 75 years old male patient, who has coxarthrosis (OA). His GP prescribed him NSAIDs, which are covered by his health insurance. NSAIDs were effective in relieving the pain and improving the functioning, but the patient also consulted an orthopaedist, who suggested using cox-2-inhibitors which are actually not covered by the health insurance. Dusan Smilic now asks his GP what he should do. You as a GP are sure that there is no necessity to change the treatment which is effective and cheap into a treatment with similar effectiveness but being 10 times more expensive.

How should the GP demonstrate now the role of advocate of the patient?

He should contact the specialist and ask why the specialist decided to change the treatment, explain his own personal opinion regarding this issue, also the patient's problems relating the more expensive treatment.

Then he should suggest the patient not to change the treatment and explain why there is no need.

\begin{tabular}{l|l|l}
\hline Features of this ability & Assessment method & Who could assess? \\
\hline $\begin{array}{l}\text { Does the GP demonstrate active } \\
\text { advocacy against the third party }\end{array}$ & - Simulated patients & - Trainer \\
(in this case orthopaedist)? & - Video observation & - Simulated patient \\
& & - Observer observation \\
\hline
\end{tabular}

Table 10: To act as advocate for the patient 